\title{
ANALISIS PERBANDINGAN TOOLKIT PURAN FILE RECOVERY, GLARY UNDELETE DAN RECUVA DATA RECOVERY UNTUK DIGITAL FORENSIK
}

\author{
Handrizal \\ Program Studi Manajemen Informatika, AMIK Tunas Bangsa Pematangsiantar \\ Jln. Jenderal Sudirman Blok A No. 1,2,3 Pematangsiantar \\ handrizal tanjung@yahoo.com
}

\begin{abstract}
This paper presents a comparative analysis of three digital forensics toolkit for data recovery scenario that has been deleted. Toolkit used is Puran File Recovery, Glary Undelete and Recuva Data Recovery. Their ability to restore deleted data has been tested and analyzed in a USB flash drive. The results of the comparison show that this third toolkit can work well in terms of finding the data that has been deleted or in recovering the deleted data.
\end{abstract}

Keywords: Data, Recovery, Forensik, Puran, Glary, Recuva

\begin{abstract}
Abstrak
Makalah ini menyajikan analisa perbandingan tiga toolkit digital forensik untuk skenario pemulihan data yang sudah dihapus. Toolkit yang digunakan adalah Puran File Recovery, Glary Undelete dan Recuva Data Recovery. Kemampuan mereka dalam pemulihan data yang dihapus telah diuji dan di analisa dalam sebuah USB flash drive. Hasil dari perbandingan menunjukkan bahwa ketiga toolkit ini dapat berkerja dengan baik dalam hal menemukan data yang sudah dihapus maupun dalam memulihkan data yang sudah dihapus tersebut.
\end{abstract}

Kata Kunci : Data, Recovery, Forensik, Puran, Glary, Recuva

\section{PENDAHULUAN}

Kemajuan dibidang teknologi seperti media massa, game online, dan media social seperti facebook, twitter, instagram telah menjangkiti kehidupan dalam bermasyarakat, khususnya generasi muda. Salah satu dampak negatif yang ditimbulkan dari kemajuan teknologi ini adalah penyalahgunaan teknologi tersebut untuk kejahatan. Kejahatan yang berkaitan dengan penggunaan komputer pada media tersebut biasanya dikenal dengan nama cybercrime.

Walaupun kejahatan cybercrime umumnya mengacu kepada aktivitas kejahatan dengan komputer atau jaringan komputer sebagai unsur utamanya, istilah ini juga digunakan untuk kegiatan kejahatan tradisional di mana komputer atau jaringan komputer digunakan untuk mempermudah atau memungkinkan kejahatan itu terjadi. Contoh kejahatan cybercrime di mana komputer sebagai alat adalah spamming dan kejahatan terhadap hak cipta dan kekayaan intelektual. Contoh kejahatan cybercrime di mana komputer sebagai sasarannya adalah akses ilegal (mengelabui kontrol akses), malware dan serangan DoS. Contoh kejahatan cybercrime di mana komputer sebagai tempatnya adalah penipuan identitas. 
Sedangkan contoh kejahatan tradisional dengan komputer sebagai alatnya adalah pornografi anak dan judi online.

Perilaku cybercrime sudah tentu sangat merugikan korbannya dan bertentangan dengan hukum. Untuk memberi hukuman kepada pelaku cybercrime ini pihak berwajib biasanya akan mencari beberapa alat bukti. Salah satu alat bukti adalah komputer yang digunakan oleh pelaku. Data yang ada didalam komputer akan diambil sebagai alat bukti dalam menghukum pelaku cybercrime. Dalam prakteknya data didalam komputer tersebut sudah dihapus oleh pelaku sebelum komputer tersebut disita oleh pihak berwajib. Dalam hal inilah diperlukan toolkit untuk memulihkan data yang sudah dihapus tersebut. Saat ini sudah banyak toolkit yang terdapat dipasaran yang dapat dimanfaatkan untuk mengembalikan data yang sudah dihapus tersebut antara lain, Puran File Recovery, Glary Undelete dan Recuva Data Recovery. Untuk mengetahui kemampuan ketiga toolkit tersebut maka penulis melakukan penelitian dengan judul "Analisis Perbandingan Toolkit Puran File Recovery, Glary Undelete Dan Recuva Data Recovery Untuk Digital Forensik".

\section{METODOLOGI PENELITIAN}

\subsection{Data Recovery}

Menurut Tim EMS[1], Data recovery adalah proses pengembalian data dari kondisi yang rusak, gagal, korup, atau tidak bisa diakses ke kondisi awal yang normal. Data yang dikembalikan bisa dari hardisk, flash disk dan media simpan lainnya seperti camera digital dan camcorder. Karena fungsinya adalah untuk menggembalikan data yang hilang maka proses data recovery ini bisa digunakan dalam konteks komputer forensik atau untuk mata-mata.

\subsection{Digital Forensik}

Menurut Lazaridis[2], Digital forensik adalah ilmu yang membahas penemuan, validasi dan interpretasi bukti digital yang ditemukan pada perangkat elektronik yang sesuai dengan kejatahan komputer. Sedangkan menurut Sulianta[3], Digital forensik adalah pengaplikasian ilmu pengetahuan dalam mengidentifikasi, mengumpulkan, menguji, dan menganalisa data, kemudian menghadirkan informasi yang dapat diandalkan.

\subsection{Puran File Recovery}

Menurut Eric[4], Puran file recovery adalah program recovery file besar dan salah satu toolkit yang bagus. Sedangkan menurut Mathew[5], Puran file recovery adalah program recovery file yang bisadigunakan untuk berbagai media penyimpan antara lain, PC Hard Drive, USB dan masih banyak lagi yang lainnya.

\subsection{Glary Undelete}

Menurut Softonic [6] Glary Undelete adalah gratis dan mudah digunakan namun sangat bagus untuk solusi file yang sudah terhapus file berlaku pada file sistem FAT dan NTFS. Glary Undelete akan membawa kembali file yang sudah dikosongkan dari Recycle Bin, dalam jendela DOS, dari Windows Explorer dengan 
tombol SHIFT ditekan. Bahkan akan memulihkan file yang telah dihapus oleh bug, crash dan virus.

\subsection{Recuva Data Recovery}

Recuva merupakan software recovery file penting yang digunakan untuk memulihkan file yang dihapus oleh pengguna dari PC Windows, recycle bin atau dari MP3 player[7]. Menurut Kamble[8], Recuva merupakan software yang bekerja secara terpadu untuk memulihkan semua data, file, photo hanya dengan satu kali klik.

\section{HASIL DAN PEMBAHASAN}

\subsection{Implementasi}

Penerapan toolkit Puran file recovery, Glary Undelete dan Recuva data recovery dilakukan pada sistem operasi windows 7 . Ketiga toolkit ini adalah software yang bisa didownload secara gratis. Setelah ketiga sorftware tersebut didownlaod kemudian diinstall, tampilan awal untuk toolkit Puran file recovery seperti pada gambar 1 dibawah ini:

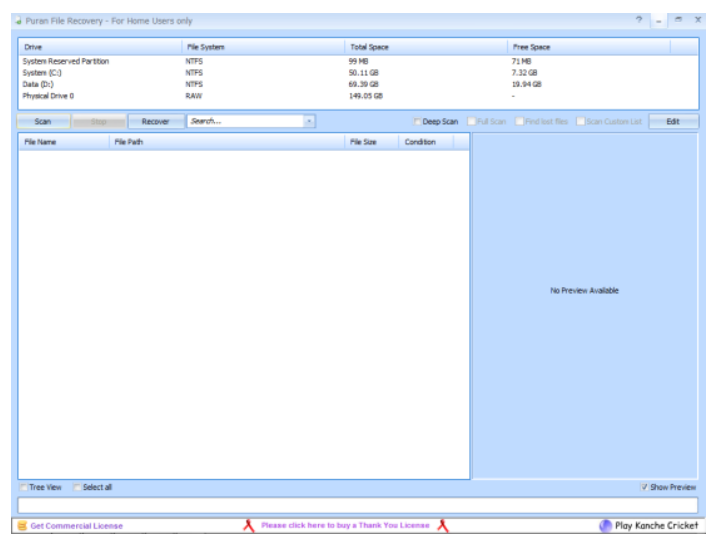

Gambar 1. Tampilan awal Puran file recovery.

Sedangkan tampilan awal untuk toolkit Glary Undelete seperti terlihat pada gambar 2 dibawah ini:

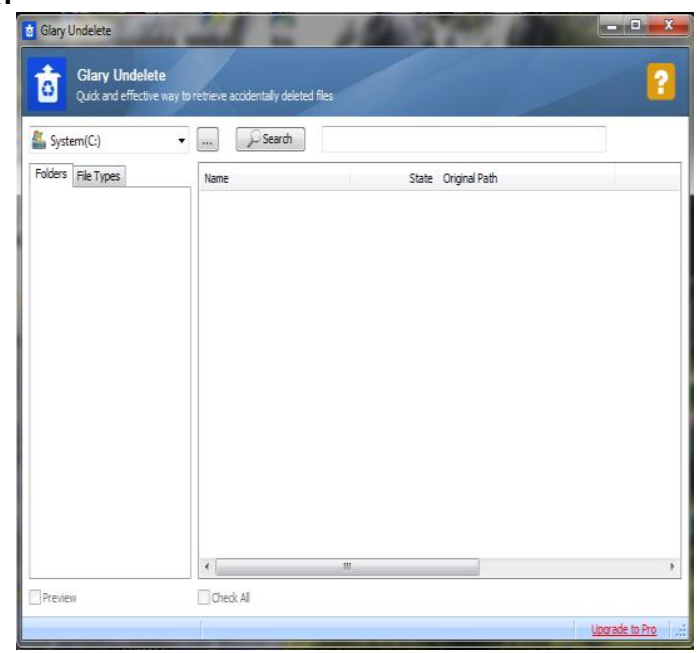

Gambar 2. Tampilan awal Glary Undelete. 
Sedangkan tampilan awal untuk toolkit Recuva data recovery seperti terlihat pada gambar 3 dibawah ini:

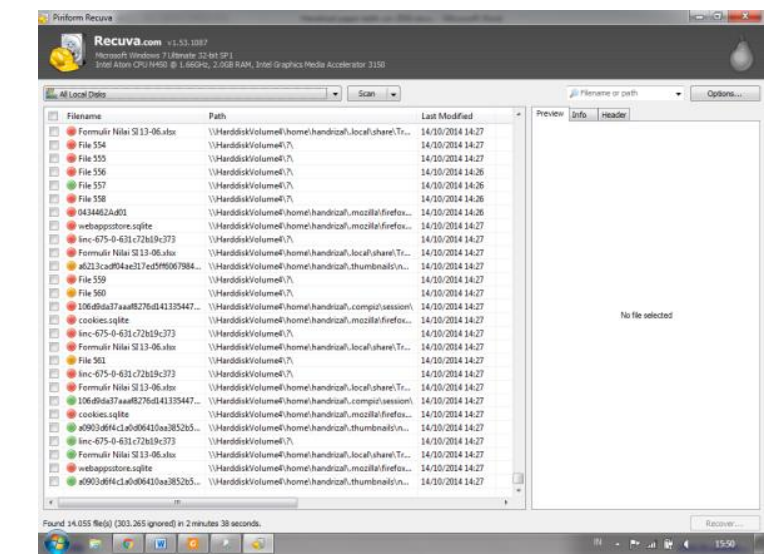

Gambar 3. Tampilan awal Puran file recovery.

\subsection{Pengujian}

pengujian ketiga toolkit ini dilakukan untuk mengetahui bagaimana kinerja toolkit dalam pencarian data yang sudah dihapus didalam sebuah flash drive Dalam pengujian ini akan dilihat hasilnya berdasarkan banyaknya jumlah data yang dapat discan dan jumlah data yang dapat dipulihkan. Tahap pertama pengujian akan dilakukan dengan menggunakan toolkit Puran file recovery. Kemudian pengujian dilanjutkan dengan toolkit Glary Undelete dan terakhir dengan Recuva data recovery. Tahap-tahap pengujian untuk masing-masing toolkit seperti berikut:
a. Format flash drive.
b. Copy sepuluh buah file dari drive $\mathrm{D}$ ke flash drive.
c. Hapus semua data didalam flash drive.
d. Kosongkan recycle bin.
e. Operasikan toolkit

\subsection{Pengujian Puran File Recovery}

Pada pengujian dengan Puran file recovery dilakukan dengan langkahlangkah berikut ini:

1. Masukkan USB flash drive ke port USB.

2. Jalankan aplikasi Puran file recovery. Pada langkah ini akan didapatkan tampilan pada layar aplikasi seperti gambar 4 berikut ini: 


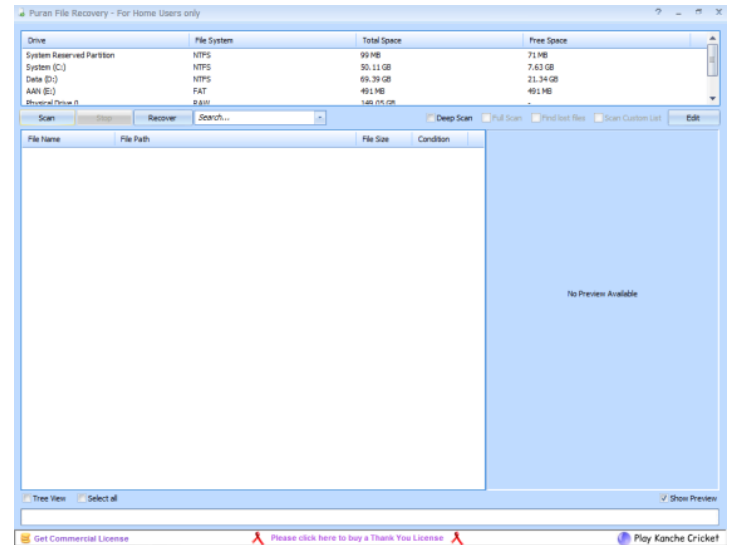

Gambar 4. USB flash drive di Puran file recovery

3. Pilih USB flash drive, kemudian klik "scan" dengan tampilan seperti pada gambar 5 berikut ini:

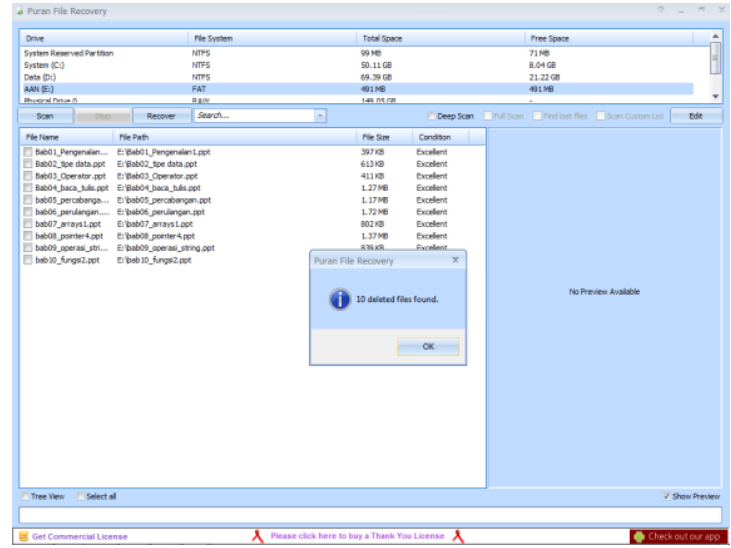

Gambar 5. Proses scanning pada USB flash drive

4. Langkah selanjutnya beri tanda ceklist pada file yang akan direcovery kemudian klik "Recovery" dan tentukan dan pilih "Just Recover", seperti pada gambar 6 berikut ini:

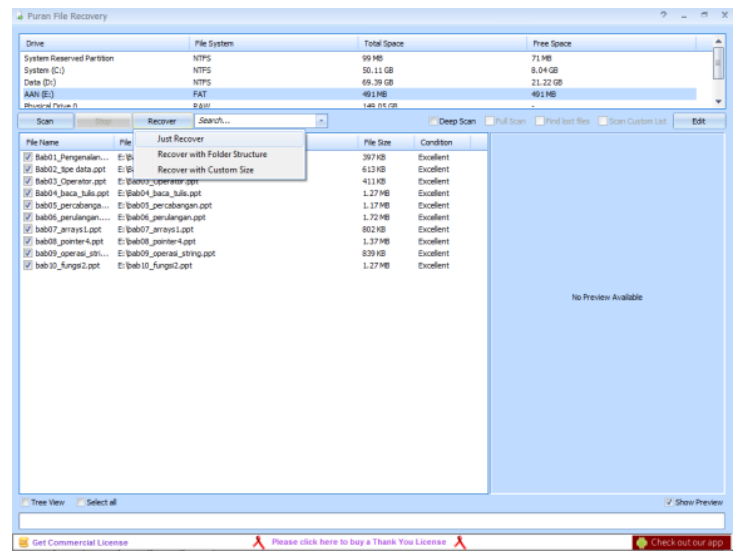

Gambar 6. Pemilihan file yang akan di recovery

5. Pilih tempat penyimpan file setelah di recovery, seperti terlihat pada gambar 7 berikut ini: 


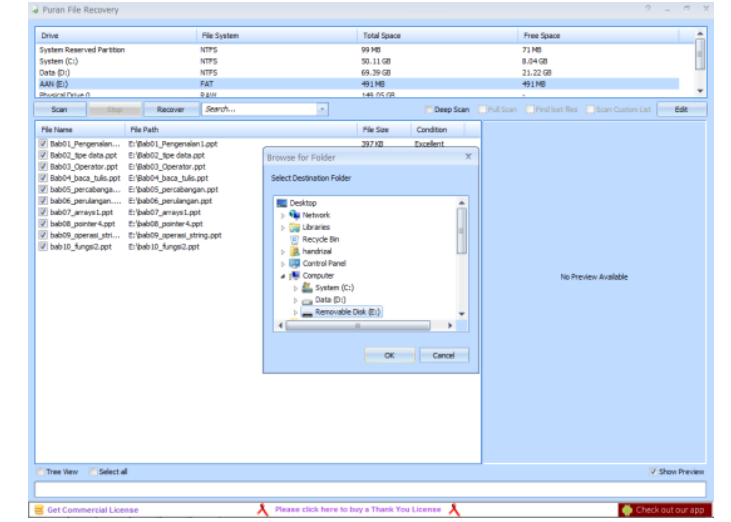

Gambar 7. Penentuan tempat penyimpanan

6. Setelah proses recovery berhasil, langkah selanjutnya melihat file tersebut pada USB flash drive, seperti pada gambar 8 berikut ini:

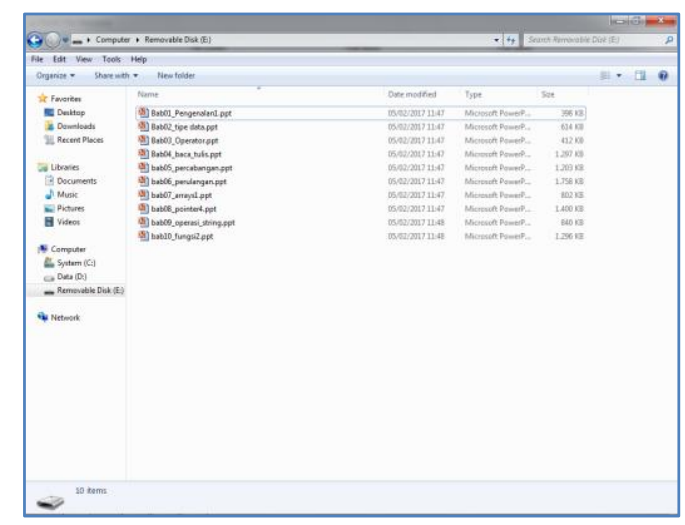

Gambar 8. Hasil akhir recovery

\subsection{Pengujian Glary Undelete}

Pada pengujian dengan Puran file recovery dilakukan dengan langkah-langkah berikut ini:

1. Masukkan USB flash drive ke port USB.

2. Jalankan aplikasi Puran file recovery. Pada langkah ini akan didapatkan tampilan pada layar aplikasi seperti gambar 9 berikut ini:

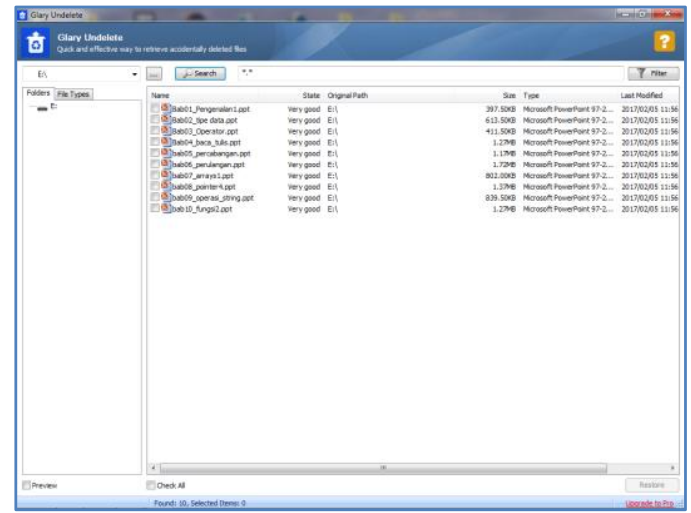

Gambar 9. Hasil scanning pada USB flash drive 
3. Langkah selanjutnya beri tanda ceklist pada file yang akan direcovery kemudian klik "Restore" seperti pada gambar 10 berikut ini:

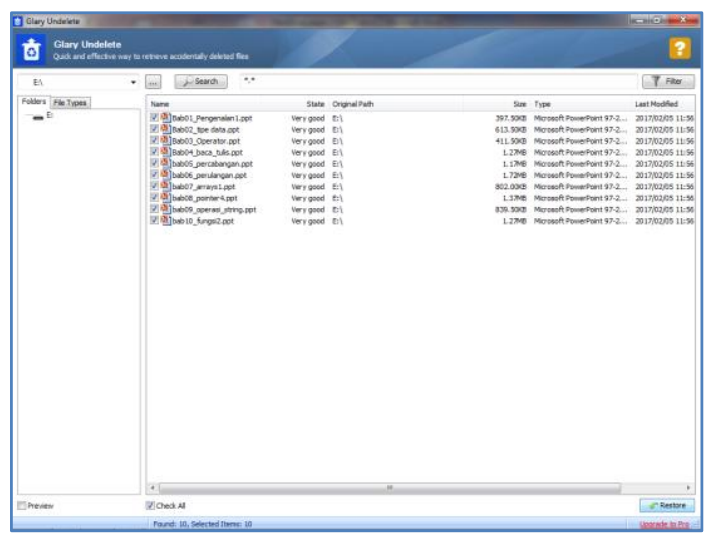

Gambar 10. Pemilihan file yang akan di recovery

4. Pilih tempat penyimpan file setelah di recovery, seperti terlihat pada gambar 11 berikut ini:

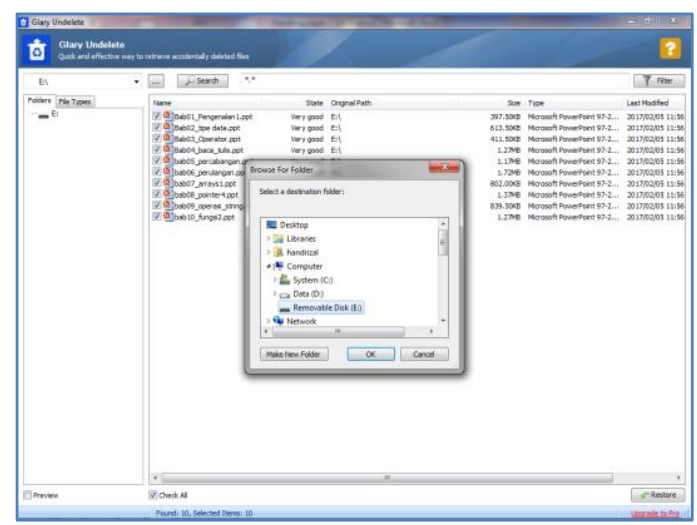

Gambar 11. Penentuan tempat penyimpanan

5. Setelah proses recovery berhasil, langkah selanjutnya melihat file tersebut pada USB flash drive, seperti pada gambar 12 berikut ini:

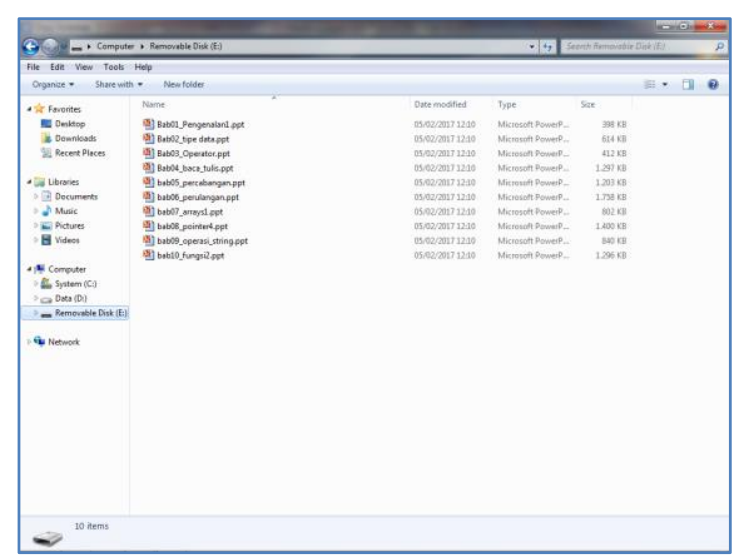

Gambar 12. Hasil akhir recovery 


\subsection{Pengujian Recuva Data Recovery}

Untuk pengujian dengan Recuva data recovery dilakukan dengan langkahlangkah berikut ini:

1. Masukkan USB flash drive ke port USB.

2. Jalankan aplikasi Recuva data recovery.

Pada langkah ini akan didapatkan tampilan pada layar aplikasi seperti gambar 13 berikut ini:

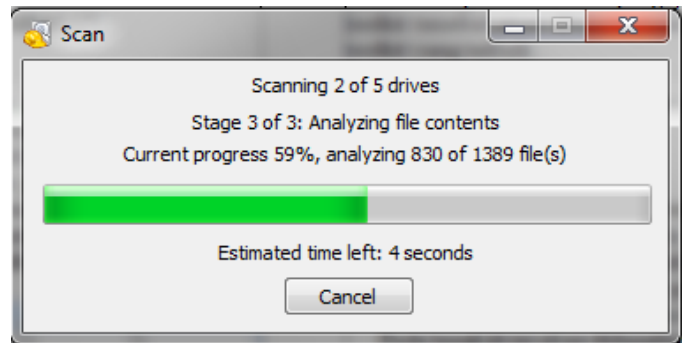

Gambar 13. Proses scanning semua drive

3. Setelah proses scanning semua drive selesai, akan tampil hasil scanning semua drive tersebut seperti terlihat pada gambar 14 berikut ini:

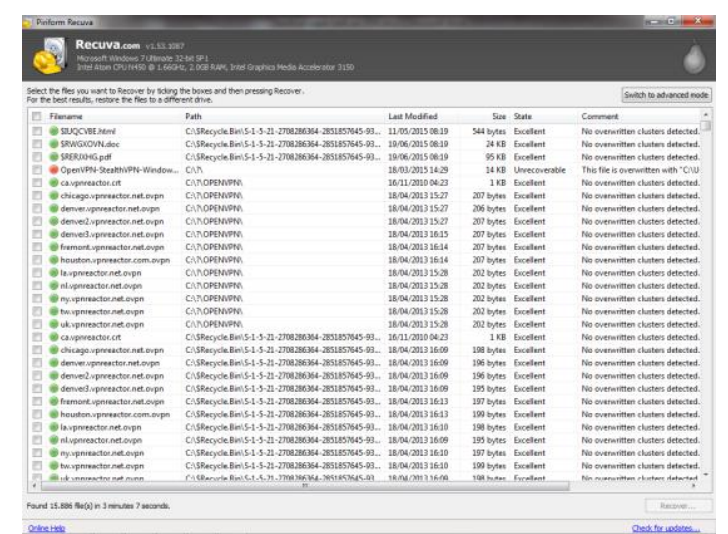

Gambar 14. Hasil scanning semua drive

4. Untuk memilih drive tertentu, klik pada bagian "Switch to advanced mode", kemudian akan tampil seperti gambar 15 berikut ini:

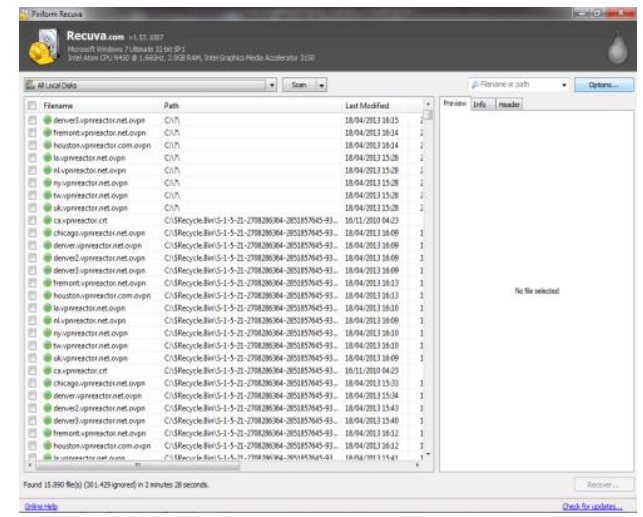

Gambar 15. Tampilan mode advanced 
5. Klik pada tulisan 'All local disks", kemudian pilih USB flash drive. Pada proses ini akan tampil seperti gambar 16 berikut ini:

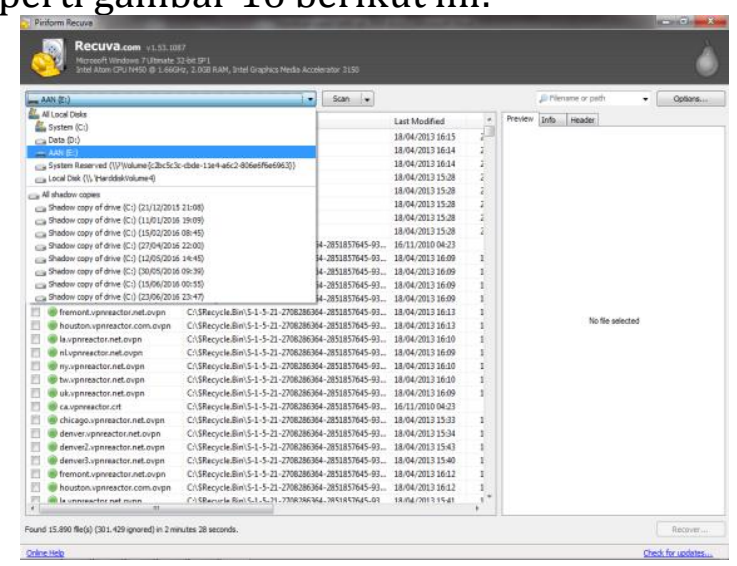

Gambar 16. Proses pemilihan drive

6. Kemudian setelah drive USB flash di pilih, langkah selanjutknya klik "scan". Proses ini akan tampil seperti gambar 17 berikut ini:

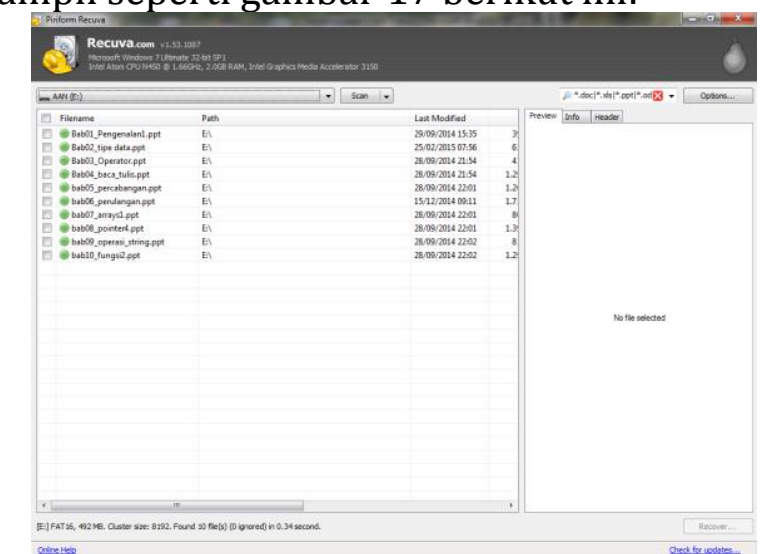

Gambar 17. Proses scanning USB flash drive

7. Langkah selanjutnya beri tanda ceklist pada file yang akan direcovery, seperti pada gambar 18 berikut ini:

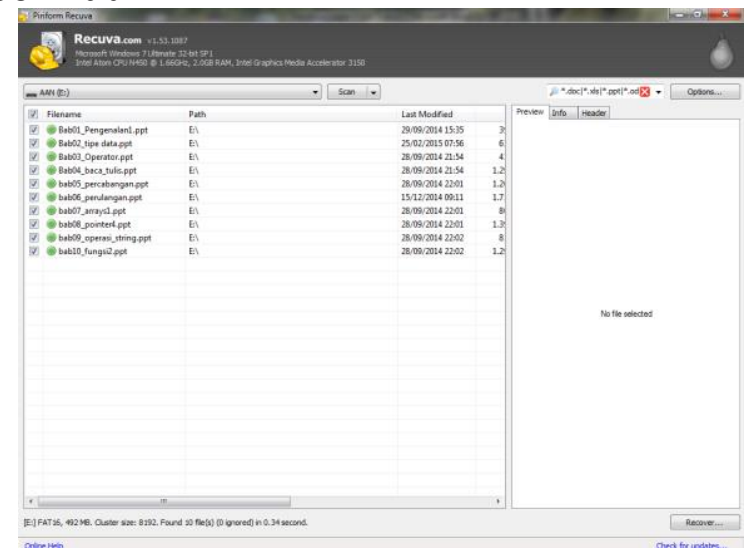

Gambar 18. Pemilihan file yang akan direcovery 
8. Langkah selanjutnya klik "Recovery" dan tentukan tempat penyimpan file yang akan direcovery, seperti pada gambar 19 berikut ini:

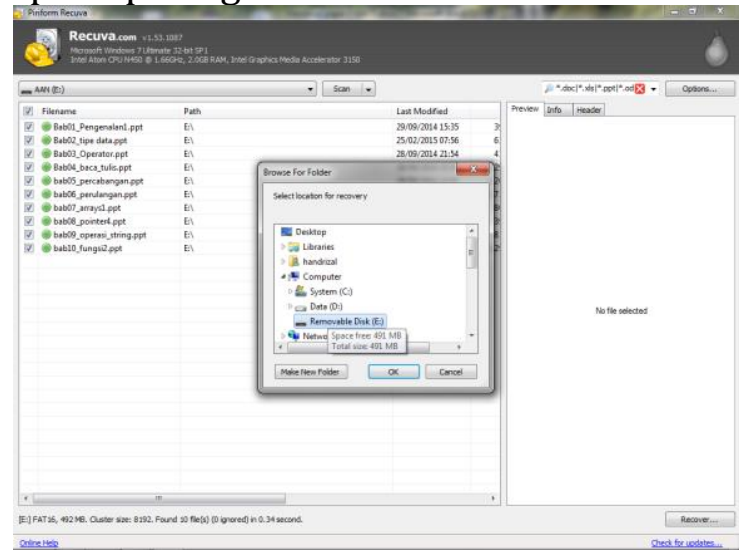

Gambar 19. Proses recovery file

9. Setelah proses recovery berhasil, langkah selanjutnya melihat file tersebut pada USB flash drive, seperti pada gambar 20 berikut ini:

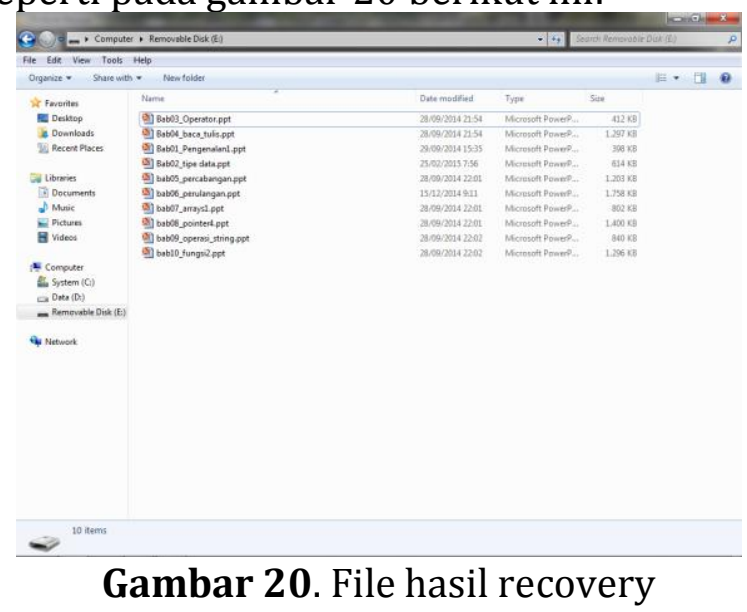

\subsection{Hasil Pengujian}

Dari pengujian yang sudah dilakukan menggunakan USB flash drive seperti disebutkan diatas, diperoleh hasil seperti terlihat pada tabel 1 berikut ini:

Tabel 1: Perbandingan Puran file recovery, Glary Undelete, dan Recuva data recovery

\begin{tabular}{|c|c|c|c|c|}
\hline No & Parameter & Puran & Glary & Recuva \\
\hline 1 & Jumlah data yang berhasil di scan & 10 & 10 & 10 \\
\hline 2 & Jumlah data yang berhasil di recovery & 10 & 10 & 10 \\
\hline
\end{tabular}

Berdasarkan tabel 1 diketahui bahwa ketiga toolkit yang digunakan dapat menemukan semua file yang sudah dihapus dan dapat memulihkan kembali semua file yang sudah dihapus tersebut. Dalam percobaan ini jumlah file yang dihapus sebanyak 10 file untuk ketiga toolkit tersebut. 


\section{KESIMPULAN}

\subsection{Kesimpulan}

Berdasarkan penelitian yang telah dilakukan diatas dapat ambil kesimpulan, antara lain:

1. Toolkit Puran file recovery, Glary Undelete dan Recuva data recovery dapat menemukan semua file yang sudah dihapus dalam sebuah flash drive dan sudah dikosong dari recycle bin.

2. Toolkit Puran file recovery, Glary Undelete dan Recuva data recovery dapat memulihkan semua file yang sudah dihapus dalam sebuah flash drive.

\subsection{Saran}

1. Untuk mengetahui lebih jauh mengenai kemampuan ketiga toolkit ini, disarankan untuk melakukan pengujian terhadap media penyimpan yang lain.

2. Selain ketiga toolkit yang sudah diuji dalam penelitian ini, masih banyak toolkit yang lainnya. Untuk itu disaran agar melakukan penelitian dengan menggunakan toolkit yang lain tersebut.

\section{DAFTAR PUSTAKA}

[1]. Tim EMS (2009), Mengatasi Data Hilang dan Serangan Virus. Elex Media Komputindo.

[2]. Ioannis Lazaridis, dkk(2016), Evaluation of Digital Forensics Tools on Data Recovery and Analysis, Prosiding The Third International Conference on Computer Science, Computer Engineering and Social Media(CSCESM2016).

[3]. Feri Sulianta(2008), Komputer Forensik, Elex Media Komputindo.

[4]. Eric(2013), Puran file recovery is one cool tool. https://tweakhound.com/2013/02/26/puran-file-recovery-is-one-cool-tool/

[5]. Mathew Blank (2014),File Data Recovery: PC Hard Drive Data Recovery, USB Data Recovery, Mac Data Recovery, Android Data Recovery, Data Recovery Services.

[6]. Softonic. [Online]. http://www.glarysoft.com/glary-undelete Accessed on October 25, 2016.

[7]. Recuva. [Online]. https://www.piriform.com/recuva. Diakses pada tanggal 15 September 2016.

[8]. Dhwaniket Ramesh Kamblea, dkk(2015), Comparison of Digital Forensic tools used in DFAI system. International Journal of Innovative and Emerging Research in Engineering, Vol 2, No 6, hal 26-35. 